\title{
A systematic review: comparative analysis of the effects of propofol and sevoflurane on postoperative cognitive function in elderly patients with lung cancer
}

Haitao Sun ${ }^{1+}$, Guohua Zhang ${ }^{1+}$, Bolun $\mathrm{Ai}^{2+}$, Huimin Zhang ${ }^{3+}$, Xiangyi Kong ${ }^{2+}$, Wan-Ting Lee ${ }^{4}$, Hui Zheng ${ }^{1}$, Tao Yan ${ }^{* *}$ and Li Sun ${ }^{5^{*}}$

\begin{abstract}
Background: The potential risk for cognitive impairment following surgery and anesthesia is a common concern, especially in the elderly and more fragile patients. The risk for various neurocognitive effects is thus an area of importance. The independent impact of surgery and anesthesia is still not known. Likewise, the independent effect of different drugs used during anesthesia is a matter of debate, as is the number and amounts of drugs used and the "depth of anesthesia." So, understanding the drug-related phenomenon and mechanisms for postoperative cognitive impairment is essential. This meta-analysis aims to compare the effects of propofol and sevoflurane anesthesia on postoperative cognitive function in elderly patients with lung cancer.

Methods: This study is a systematic review and meta-analysis for controlled clinical studies. Public-available online databases were searched to identify eligible randomized placebo-controlled trials or prospective cohort studies concerning the effects of propofol and sevoflurane on postoperative cognitive function. The primary endpoints are postoperative mini-mental state examination (MMSE) scores at various time points; the secondary endpoint is the serum S100beta concentration $24 \mathrm{~h}$ after surgery. Standard mean differences (SMDs) along with 95\% confidence intervals (Cls) were extracted and analyzed using random or fixed-effects models. Analyses regarding heterogeneity, risk of bias assessment, and sensitivity were performed.

(Continued on next page)
\end{abstract}

\footnotetext{
*Correspondence: blizzardyt@163.com; yantaoncc1@163.com;

lilysun0008@aliyun.com

${ }^{\dagger}$ Haitao Sun, Guohua Zhang, Bolun Ai, Huimin Zhang and Xiangyi Kong contributed equally to this work.

'Department of Anesthesiology, National Cancer Center/National Clinical Research Center for Cancer/Cancer Hospital, Chinese Academy of Medical Sciences and Peking Union Medical College, Beijing 100021, China

${ }^{5}$ Department of Anesthesiology, National Cancer Center/National Clinical Research Center for Cancer/Cancer Hospital \& Shenzhen Hospital, Chinese Academy of Medical Sciences and Peking Union Medical College, Shenzhen 518116, China

Full list of author information is available at the end of the article
}

(c) The Author(s). 2019 Open Access This article is distributed under the terms of the Creative Commons Attribution 4.0 International License (http://creativecommons.org/licenses/by/4.0/), which permits unrestricted use, distribution, and reproduction in any medium, provided you give appropriate credit to the original author(s) and the source, provide a link to the Creative Commons license, and indicate if changes were made. The Creative Commons Public Domain Dedication waiver (http://creativecommons.org/publicdomain/zero/1.0/) applies to the data made available in this article, unless otherwise stated. 


\begin{abstract}
(Continued from previous page)
Results: We searched 1626 eligible publications and 14 studies of 1404 patients were included in the final analysis. The majority of included studies had been undertaken in Asian populations. Results suggested that propofol has a greater adverse effect on cognitive function in the elderly patients with lung cancer than sevoflurane. There were significant differences in issues of MMSE $6 \mathrm{~h}$ (11 studies; SMD -1.391, 95\% Cl -2.024, $-0.757 ; p<0.001$ ), MMSE $24 \mathrm{~h}$ (14 studies; SMD -1.106, 95\% Cl -1.588, - 0.624; $p<0.001$ ), MMSE 3d (11 studies; SMD -1.065, 95\% Cl -1.564, - 0.566; $p<0.001$ ), MMSE $7 d$ (10 studies; SMD $-0.422,95 \% \mathrm{Cl}-0.549,-0.295 ; p<0.001)$, and serum S100beta concentration at 1 day after surgery (13 studies; SMD 0.746, 95\% Cl 0.475, 1.017; $p<0.001$ ).

Conclusion: Propofol has a more significant adverse effect on postoperative cognitive function in elderly patients with lung cancer than sevoflurane.
\end{abstract}

Keywords: Propofol, Sevoflurane, Cognitive function, Lung Cancer, Meta-analysis

\section{Background}

Cognitive impairment is a neurological disorder that occurs in adults, which involves cognitive disorders with impairment in instrumental activities of daily living $[1,2]$. Previous studies have shown that about 234 million patients worldwide undergo surgery each year, and about $41 \%$ of elderly patients have cognitive impairment after surgery or anesthesia. Thirteen percent of patients still have cognitive impairment 3 months after discharge [3, 4]. Cognitive impairment severely affects the prognosis of patients who have undergone general anesthesia surgeries, especially elderly patients, including decreased quality of life, loss of independence, and increased mortality [5]. Patients with lung cancer frequently encounter postoperative cognitive dysfunction. In elderly patients, severe cognitive impairment is more likely to occur after anesthesia. This may be due to a combination of multiple factors, such as inflammation caused by surgical trauma, infection, opioids, stress, and sleep disorders [6]. Because the incidence of cognitive impairment is positively correlated with the duration of anesthesia, general anesthetic drugs are thought to be one of the causes of cognitive impairment in elderly patients [7].

Worldwide, lung cancer occurred in approximately 1.8 million patients in 2012 and caused an estimated 1.6 million deaths [8]. This is increased from 1.6 million new diagnoses and 1.4 million lung cancer deaths in 2008 [9]. The treatment for early-stage lung cancer is mainly surgical treatment. Propofol and sevoflurane are the most commonly used general anesthetic drugs in clinical practice [10]. However, in terms of causing postoperative cognitive functions, there are still controversies regarding the use of propofol anesthesia or sevoflurane anesthesia in elderly patients with lung cancer. Current published studies on this topic were with relatively smaller sample sizes and were lack of consistency. Therefore, we conducted this systematic review and meta-analysis to derive a pooled estimate of the effects of propofol and sevoflurane on postoperative cognitive functions in patients with lung cancer, with an improved statistical power as compared to individual studies. The primary endpoints are postoperative mini-mental state examination (MMSE) scores at various time points; the secondary endpoints are serum S100beta concentration $24 \mathrm{~h}$ after surgery. S100 $\beta$ is glial-specific and is expressed primarily by astrocytes. It functions in the process of neurite extension, proliferation of melanoma cells, stimulation of $\mathrm{Ca} 2+$ fluxes, inhibition of PKC-mediated phosphorylation, astrocytosis, axonal proliferation, and inhibition of microtubule assembly. In the developing central nervous system (CNS), it acts as a neurotrophic factor and neuronal survival protein. In the adult organism, it is usually elevated due to nervous system damage, which makes it a potential clinical marker. S100 $\beta$ is involved in the regulation of cell shape, cell growth, energy metabolism, cell-to-cell communication, contraction, and intracellular signal transduction. The correlation between serum S100 $\beta$ protein levels and cognitive dysfunction.

\section{Methods}

\section{Research protocol overview}

Public-available online databases were searched to identify eligible randomized placebo-controlled trials or prospective cohort studies concerning the effects of propofol and sevoflurane on postoperative cognitive function. The primary endpoints are postoperative mini-mental state examination (MMSE) scores at various time points; the secondary endpoint is the serum S100beta concentration $24 \mathrm{~h}$ after surgery. Standard mean differences (SMDs) along with 95\% confidence intervals (CIs) were extracted and analyzed using random or fixed-effects models. Analyses regarding heterogeneity, risk of bias assessment, and sensitivity were performed.

\section{Search strategies}

We searched the databases of Embase, Pubmed, The Cochrane Library, Web of Science, and China National Knowledge Infrastructure (CNKI). Retrieval time is from the database construction time to March 2018. The English search words include propofol, sevoflurane, cognitive, and lung cancer. The Chinese search words are the Chinese translation of the above words. There are no 
language and time limits. For the retrieved documents, we further tracked their references to include the ones that met the inclusion criteria.

\section{Inclusion and exclusion criteria}

This study analyzed studies with a population of $>60$ yearsold, ASA class I to III patients who had scheduled for lung cancer surgeries, and received propofol or sevoflurane during anesthesia. The primary endpoints are postoperative mini-mental state examination (MMSE) scores at various time points; the secondary endpoint is serum S100beta concentration $24 \mathrm{~h}$ after surgery. Specific inclusion criteria and exclusion criteria were reported in Table 1.

\section{Data extraction and quality evaluation}

Two researchers independently conducted literature screening and quality evaluation of the obtained documents. In case of disagreement, they would reach an agreement by discussion or invite a third party to adjudicate. Data extraction: 1) necessary information included in the study, such as first author and publication date; 2) general data of patients in the experimental group and control group, such as the sex, age, America Society of Anesthesiologist (ASA) classification, intervention measures, operations, etc.; 3) anesthesia methods, including methods of inducing anesthesia and maintenance of anesthesia, and the drug doses; 4) outcomes, including preoperative and postoperative MMSE scores, changes in serum S100beta concentration before and after surgery. The main characteristics of the included studies were summarized in Table 2.

Quality Evaluation: The Cochrane System Evaluation Criteria was used for this evaluation. We used the Cochrane Risk Bias Assessment Tool to analyze the literature bias [11].

\section{Patient involvement}

There was no patient involvement in the design and implementation of this study.

\section{Statistical analysis}

The primary endpoints are postoperative mini-mental state examination (MMSE) scores at various time points; the secondary endpoint is serum S100beta concentration $24 \mathrm{~h}$ after surgery. STATA 13.0 (StataCorp LP, College Station, TX, USA) software was used for statistical analysis. In order to eliminate the influence of different units and differences in the means among different research studies, we analyzed the standard mean difference (SMD) and its 95\% CI. We used the Galbr plot, $\mathrm{I}^{2}$ test and Cochran's Q-test to determine whether the results are heterogeneous, and at the same time, we analyzed the heterogeneity by calculating $\mathrm{I}^{2}$. If the $P$ value $>0.1$ and $\mathrm{I} 2<50 \%$, the heterogeneity between the results is

Table 1 Inclusion criteria for study selection in this meta-analysis

\begin{tabular}{l}
\hline Number \\
1 \\
2 \\
3 \\
4 \\
5 \\
6 \\
Number \\
1 \\
2 \\
3 \\
4 \\
5 \\
6 \\
\hline
\end{tabular}

Inclusion criteria

Original prospective cohort studies or randomized controlled trials (RCTs) published in full text and those for which we had full access to all original data and protocols.

The studies evaluated the differences of the effect of propofol and sevoflurane on postoperative cognitive functions.

Regarding the intervening measures between different groups, the only difference is that the two groups received propofol or sevoflurane, respectively. Other conditions should be the same.

\section{Human studies.}

Predefined outcomes: incidence of postoperative MMSE scores and the plasma protein $\mathrm{S} 100 \beta$ at various time points.

No minimal sample size or dosing regimen was required for inclusion.

Exclusion criteria

The study did not have a control group of patients without propofol use or sevoflurane use.

They were case studies or case series.

The report focused exclusively on other topics or outcomes.

No human data were included.

Except for the difference of anaesthetic administration, there were other differences between the experimental groups and the control groups.

Reviews and duplicated publications. 
Table 2 Characteristics of studies included in the meta-analysis

\begin{tabular}{|c|c|c|c|c|c|c|c|c|c|c|c|}
\hline \multirow[t]{2}{*}{ Author } & \multirow[t]{2}{*}{ Year } & \multirow[t]{2}{*}{ Country } & \multirow{2}{*}{$\begin{array}{l}\text { Sex } \\
(\mathrm{M} / \\
\mathrm{F})\end{array}$} & \multirow[t]{2}{*}{ Age } & \multirow[t]{2}{*}{ Surgery } & \multirow{2}{*}{$\begin{array}{l}\text { ASA } \\
\text { grade }\end{array}$} & \multirow[t]{2}{*}{ Outcomes } & \multicolumn{2}{|l|}{ Propofol group } & \multicolumn{2}{|l|}{ Sevoflurane group } \\
\hline & & & & & & & & Method & $\overline{\text { No. }}$ & Method & $\overline{\text { No. }}$ \\
\hline $\begin{array}{l}\text { Yu } \\
\text { et al. }\end{array}$ & 2012 & China & $\begin{array}{l}44 \\
136\end{array}$ & $68.8 \pm 3.8$ & $\begin{array}{l}\text { Lung } \\
\text { cancer } \\
\text { operation }\end{array}$ & $\mid \sim \|$ & (1)(2)(3)(4)(5)(6) & $\begin{array}{l}\text { Induction: midazolam, } \\
\text { fentanyl, rocuronium, } \\
\text { etomidate; } \\
\text { Maintain: propofol }\end{array}$ & 40 & $\begin{array}{l}\text { Induction: midazolam, } \\
\text { fentanyl, rocuronium, } \\
\text { etomidate; } \\
\text { Maintain: sevoflurane }\end{array}$ & 40 \\
\hline $\begin{array}{l}\text { Tang } \\
\text { et al. }\end{array}$ & 2014 & China & $\begin{array}{l}38 \\
132\end{array}$ & $70.0 \pm 11.7$ & $\begin{array}{l}\text { Lung } \\
\text { cancer } \\
\text { operation }\end{array}$ & $|\sim| \mid$ & (1)(2)(3)(4)(5) & $\begin{array}{l}\text { Induction: etomidate, } \\
\text { midazolam, fentanyl, } \\
\text { rocuronium; } \\
\text { Maintain: propofol }\end{array}$ & 35 & $\begin{array}{l}\text { Induction: etomidate, } \\
\text { midazolam, fentanyl, } \\
\text { rocuronium; } \\
\text { Maintain: sevoflurane }\end{array}$ & 35 \\
\hline $\begin{array}{l}\text { Sun } \\
\text { et al. }\end{array}$ & 2014 & China & $\begin{array}{l}77 \\
129\end{array}$ & $72.2 \pm 2.6$ & $\begin{array}{l}\text { Lung } \\
\text { cancer } \\
\text { operation }\end{array}$ & $N$ & (1)(2)(3)(4)(5)(6) & $\begin{array}{l}\text { Induction: fentanyl and } \\
\text { vecuronium bromide; } \\
\text { Maintain: propofol 2 4 mg/ } \\
\text { kg/min }\end{array}$ & 53 & $\begin{array}{l}\text { Induction: fentanyl and } \\
\text { vecuronium bromide; } \\
\text { Maintain: sevoflurane }\end{array}$ & 53 \\
\hline $\begin{array}{l}\text { Cui } \\
\text { et al. }\end{array}$ & 2015 & China & $\begin{array}{l}94 \\
176\end{array}$ & $69 \pm 12.9$ & $\begin{array}{l}\text { Lung } \\
\text { cancer } \\
\text { operation }\end{array}$ & N & (1)(3)(5) & $\begin{array}{l}\text { Induction: fentanyl, } \\
\text { etomidate, vecuronium } \\
\text { bromide; } \\
\text { Maintain: propofol 2 4 mg/ } \\
\text { kg/min }\end{array}$ & 80 & $\begin{array}{l}\text { Induction: fentanyl, } \\
\text { etomidate, vecuronium } \\
\text { bromide; } \\
\text { Maintain: sevoflurane } \\
\text { 1\% 3\% }\end{array}$ & 80 \\
\hline $\begin{array}{l}\text { Zhang } \\
\text { et al. }\end{array}$ & 2016 & China & $\begin{array}{l}101 \\
/ 91\end{array}$ & $60.0 \pm 6.4$ & $\begin{array}{l}\text { Lung } \\
\text { cancer } \\
\text { operation }\end{array}$ & $\mathrm{N}$ & (1)(3)(4) & $\begin{array}{l}\text { Induction: midazolam, } \\
\text { fentanyl, rocuronium, } \\
\text { etomidate; } \\
\text { Maintain: propofol }\end{array}$ & 96 & $\begin{array}{l}\text { Induction: midazolam, } \\
\text { fentanyl, rocuronium, } \\
\text { etomidate; } \\
\text { Maintain: sevoflurane }\end{array}$ & 96 \\
\hline $\begin{array}{l}\text { Wang } \\
\mathrm{H} \text { et al. }\end{array}$ & 2015 & China & $\begin{array}{l}41 \\
/ 31\end{array}$ & $73.5 \pm 2.8$ & $\begin{array}{l}\text { Lung } \\
\text { cancer } \\
\text { operation }\end{array}$ & $\mid \sim \|$ & (1)(2)(3)(4)(6) & $\begin{array}{l}\text { Induction: unified rapid } \\
\text { induction; } \\
\text { Maintain: propofol }\end{array}$ & 36 & $\begin{array}{l}\text { Induction: unified rapid } \\
\text { induction; } \\
\text { Maintain: sevoflurane }\end{array}$ & 36 \\
\hline $\begin{array}{l}\text { Wang } \\
\text { F et al. }\end{array}$ & 2017 & China & $\begin{array}{l}32 \\
/ 18\end{array}$ & $72.5 \pm 3.0$ & $\begin{array}{l}\text { Lung } \\
\text { cancer } \\
\text { operation }\end{array}$ & $N$ & (1)(2)(3)(4)(6) & $\begin{array}{l}\text { Induction: midazolam, } \\
\text { fentanyl, rocuronium, } \\
\text { etomidate; } \\
\text { Maintain: propofol }\end{array}$ & 50 & $\begin{array}{l}\text { Induction: midazolam, } \\
\text { fentanyl, rocuronium, } \\
\text { etomidate; } \\
\text { Maintain: sevoflurane }\end{array}$ & 50 \\
\hline $\begin{array}{l}\text { Zhao } \\
\text { et al. }\end{array}$ & 2014 & China & $\begin{array}{l}80 \\
130\end{array}$ & $73.5 \pm 2.0$ & $\begin{array}{l}\text { Lung } \\
\text { cancer } \\
\text { operation }\end{array}$ & $|\sim| \mid$ & (1)(2)(3)(4)(5) & $\begin{array}{l}\text { Induction: fentanyl and } \\
\text { vecuronium bromide; } \\
\text { Maintain: propofol 2 4 mg/ } \\
\text { kg/min }\end{array}$ & 50 & $\begin{array}{l}\text { Induction: fentanyl and } \\
\text { vecuronium bromide; } \\
\text { Maintain: sevoflurane }\end{array}$ & 60 \\
\hline $\begin{array}{l}\text { Chen } \\
\text { et al. }\end{array}$ & 2015 & China & $\begin{array}{l}43 \\
135\end{array}$ & $69.2 \pm 3.2$ & $\begin{array}{l}\text { Lung } \\
\text { cancer } \\
\text { operation }\end{array}$ & $\mathrm{N}$ & (1)(2)(3)(4)(5) & $\begin{array}{l}\text { Induction: midazolam, } \\
\text { propofol, fentanyl and } \\
\text { vecuronium bromide; } \\
\text { Maintain: propofol } 6 \sim 10 \mathrm{mg} / \\
\text { kg/min }\end{array}$ & 39 & $\begin{array}{l}\text { Induction: midazolam, } \\
\text { propofol, fentanyl and } \\
\text { vecuronium bromide; } \\
\text { Maintain: sevoflurane }\end{array}$ & 39 \\
\hline $\begin{array}{l}\text { Huang } \\
\text { et al. }\end{array}$ & 2015 & China & $\begin{array}{l}50 \\
/ 40\end{array}$ & $68.2 \pm 1.3$ & $\begin{array}{l}\text { Lung } \\
\text { cancer } \\
\text { operation }\end{array}$ & $\mathrm{N}$ & (1)(2)(3)(4)(6) & $\begin{array}{l}\text { Induction: rocuronium, } \\
\text { fentanyl, midazolam, } \\
\text { etomidate; } \\
\text { Maintain: propofol }\end{array}$ & 45 & $\begin{array}{l}\text { Induction: rocuronium, } \\
\text { fentanyl, midazolam, } \\
\text { etomidate; } \\
\text { Maintain: sevoflurane }\end{array}$ & 45 \\
\hline $\begin{array}{l}\text { Lin } \\
\text { et al. }\end{array}$ & 2017 & China & $\begin{array}{l}54 / \\
40\end{array}$ & $\begin{array}{l}68.23 \pm \\
1.32\end{array}$ & $\begin{array}{l}\text { Lung } \\
\text { cancer } \\
\text { operation }\end{array}$ & $|\sim| \mid$ & (1)(2)(3)(4) & $\begin{array}{l}\text { Induction: propofol, } \\
\text { midazolam, vecuronium, } \\
\text { fentanyl; } \\
\text { Maintain: propofol }\end{array}$ & 40 & $\begin{array}{l}\text { Induction: propofol, } \\
\text { midazolam, vecuronium, } \\
\text { fentanyl; } \\
\text { Maintain: sevoflurane }\end{array}$ & 54 \\
\hline $\begin{array}{l}\text { Zhang } \\
\text { et al. }\end{array}$ & 2017 & China & $\begin{array}{l}41 / \\
29\end{array}$ & $\begin{array}{l}P: 74.8 \pm \\
2.1 ; S: \\
74.3 \pm 2.5\end{array}$ & $\begin{array}{l}\text { Lung } \\
\text { cancer } \\
\text { operation }\end{array}$ & $\mid \sim \|$ & (2)(3)(4) & $\begin{array}{l}\text { Induction: fentanyl, } \\
\text { etomidate, midazolam, } \\
\text { rocuronium; } \\
\text { Maintain: propofol }\end{array}$ & 35 & $\begin{array}{l}\text { Induction: fentanyl, } \\
\text { etomidate, midazolam, } \\
\text { rocuronium; } \\
\text { Maintain: sevoflurane }\end{array}$ & 35 \\
\hline $\begin{array}{l}\text { Yang } \\
\text { et al. }\end{array}$ & 2017 & China & $\begin{array}{l}84 / \\
36\end{array}$ & $71.9 \pm 2.5$ & $\begin{array}{l}\text { Lung } \\
\text { cancer } \\
\text { operation }\end{array}$ & $\mathrm{N}$ & (1)(2)(3)(4)(5) & $\begin{array}{l}\text { Induction: unified rapid } \\
\text { induction; } \\
\text { Maintain: propofol }\end{array}$ & 60 & $\begin{array}{l}\text { Induction: unified rapid } \\
\text { induction; } \\
\text { Maintain: sevoflurane }\end{array}$ & 60 \\
\hline $\begin{array}{l}\text { Tian } \\
\text { et al. }\end{array}$ & 2017 & China & $\begin{array}{l}38 / \\
24\end{array}$ & $\begin{array}{l}P: 68.3 \pm \\
13.5 ; S: \\
65.5 \pm 16.2\end{array}$ & $\begin{array}{l}\text { Lung } \\
\text { cancer } \\
\text { operation }\end{array}$ & $\mid \sim \|$ & (1)(3) & $\begin{array}{l}\text { Induction: midazolam, } \\
\text { fentanyl, propofol; } \\
\text { Maintain: propofol }\end{array}$ & 31 & $\begin{array}{l}\text { Induction: midazolam, } \\
\text { fentanyl, sevoflurane; } \\
\text { Maintain: propofol }\end{array}$ & 31 \\
\hline
\end{tabular}

$N$ Not mentioned, ASA American society of anesthesiology, (1) = Preoperative MMSE score, (2) $=$ MMSE score at $6 \mathrm{~h}$ after surgery, (3) $=$ MMSE score at 1 day after surgery, (4)= MMSE score at 3 day after surgery, (5)=MMSE score at 7 day after surgery, (6)= Plasma S100 $\beta$ protein level at 1 day after surgery, $P$ Propofol, 
not apparent, so that a fixed effect model would be used for this meta-analysis; when $P \leq 0.1$ and $\mathrm{I} 2 \geq 50 \%$, it indicates that the results of the studies are heterogeneous. If the heterogeneity is apparent, then it could be eliminated by searching for the source of heterogeneity and analyzing the sensitivity; if the source of heterogeneity is not bright, the meta-analysis would be performed using a random-effect model. A bias risk assessment tool was used to assess the risk of bias. Detailed explanations of the mentioned analyses were included in Table 3. Twotailed $P$ values less than 0.05 were considered as statistically significant.

\section{Results}

Search results

The flowchart summarizing the study selection process following the PRISMA statement was reported in Fig. 1. A total of 1626 studies were identified in the initial search, including 108 studies from PubMed, 1131 studies from EMBASE, 148 studies from Cochrane Library, 195 studies from Web of Science, 44 studies from CNKI, and one academic meeting abstracts (Table 4). After screening based on inclusion and exclusion criteria, 372 articles were retrieved as eligible and then reviewed by two independent reviewers. Finally, fourteen studies, including 1404 patients, were included in the final meta-analysis [12-25].

\section{Patient characteristics}

In terms of patient race group, all studies were performed in patients of Asian backgrounds. There was one study published in English and 13 studies in Chinese. The characteristics of the studies included in this metaanalysis were listed in Table 2 in detail.

\section{Meta-analysis results and bias assessment results}

The main results, including heterogeneity tests, effect models adopted accordingly, and the pooled SMDs with their $95 \% \mathrm{CI}$ and the $P$ value of this meta-analysis were presented in Table 5. The Galbr plots for the association between the use of narcotic drugs and postoperative cognitive function were shown in Fig. 2, suggesting that there was no heterogeneity only among the 10 studies $[12,13,15,17,19-22,24,25]$ with continuous data focusing on MMSE scores 7 days after the surgery, but not among other comparisons. Using fixed-effects model, the pooled SMD for the 10 studies was -0.422 (95\% CI: $-0.549,-0.295, Z=6.52 ; P<0.001)$, the pooled WMD was -0.371 (95\% CI: $-0.493,-0.249, \mathrm{P}<0.001)$, indicating that in terms of MMSE scores 7 days postoperatively,

Table 3 The statistical methods used in this meta-analysis and their explanation

\begin{tabular}{|c|c|c|}
\hline Goals and Usages & Statistic Methods & Explanations and Instructions \\
\hline \multirow[t]{3}{*}{ To evaluate heterogeneity between the included studies } & Galbr plot & $\begin{array}{l}\text { In Galbr figure, if the points all fall within the } \\
\text { area between the upper line and the lower } \\
\text { line, it can be taken as an evidence of } \\
\text { homogeneity; otherwise, there is heterogeneity. }\end{array}$ \\
\hline & Cochran's Q test & $\begin{array}{l}\text { Cochran's } Q \text { test is an extension to the McNemar } \\
\text { test for related samples that provides a method } \\
\text { for testing for differences between three or more } \\
\text { matched sets of frequencies or proportions. } \\
\text { Heterogeneity was also considered significant } \\
\text { if } P<0.05 \text { using the Cochran's Q test. }\end{array}$ \\
\hline & $I^{2}$ index test & $\begin{array}{l}\text { The } I^{2} \text { index measures the extent of true } \\
\text { heterogeneity dividing the difference between } \\
\text { the result of the } Q \text { test and its degrees of freedom } \\
(k-1) \text { by the } Q \text { value itself, and multiplied by } 100 . I^{2} \\
\text { values of } 25,50 \text { and } 75 \% \text { were used as evidence of } \\
\text { low, moderate and high heterogeneity, respectively. }\end{array}$ \\
\hline To examine the stability of the pooled results & Sensitivity analysis & $\begin{array}{l}\text { A sensitivity analysis was performed using the } \\
\text { one-at-a-time method, which involved omitting } \\
\text { one study at a time and repeating the meta-analysis. } \\
\text { If the omission of one study significantly changed the } \\
\text { result, it implied that the result was sensitive to the } \\
\text { studies included. }\end{array}$ \\
\hline Publication bias test & Contour-enhanced funnel plot & $\begin{array}{l}\text { Visual inspection of the Contour-enhanced funnel plots } \\
\text { was used to assess potential publication bias. Asymmetry } \\
\text { in the plots, which may be due to studies missing on the } \\
\text { left-hand side of the plot that represents low statistical } \\
\text { significance, suggested publication bias. If studies were } \\
\text { missing in the high statistical significance areas (on the } \\
\text { right-hand side of the plot), the funnel asymmetry was } \\
\text { not considered to be due to publication bias }\end{array}$ \\
\hline
\end{tabular}




\section{PRISMA PRISMA 2009 Flow Diagram}

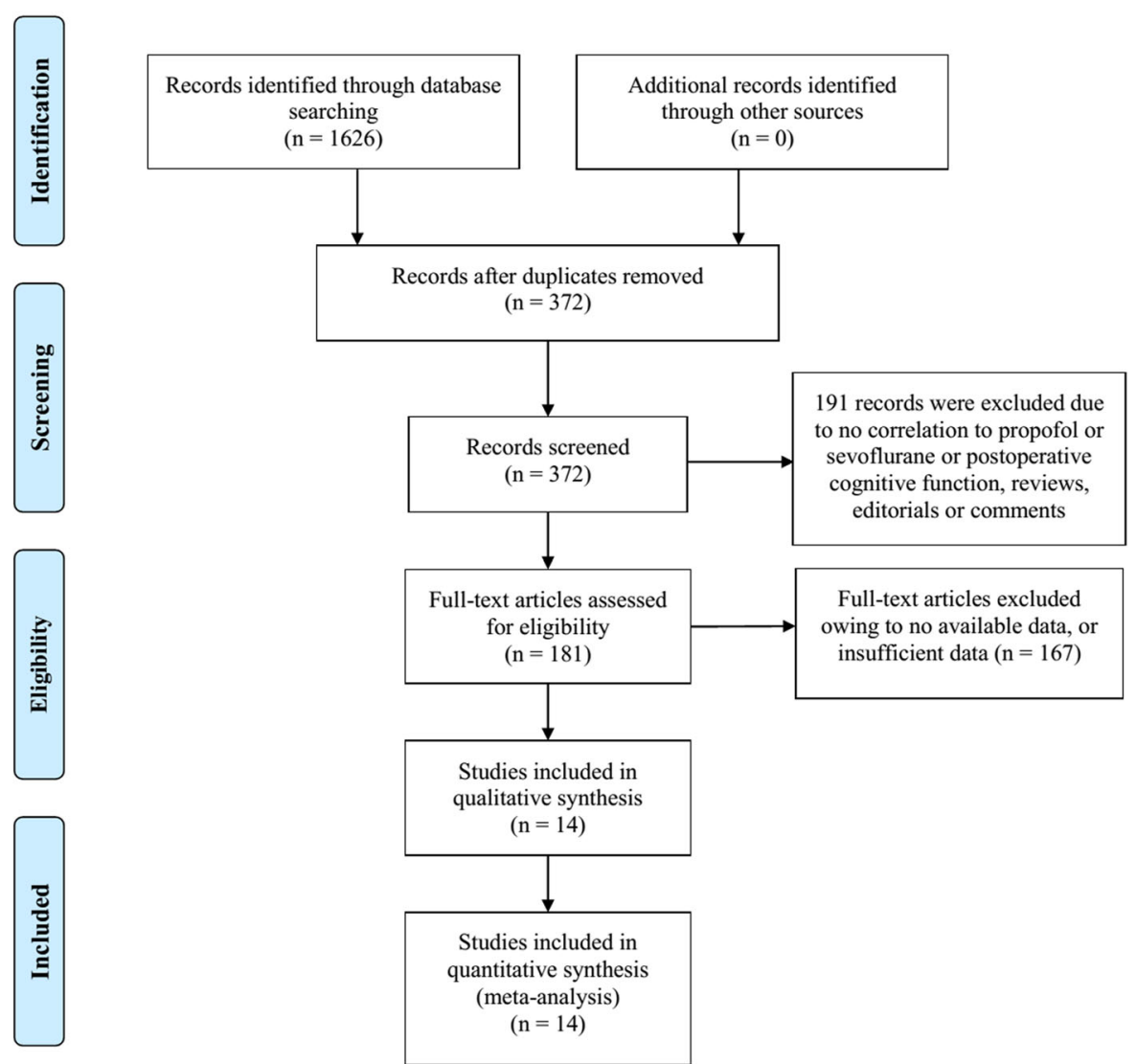

Fig. 1 Literature search and selection of articles

propofol has a greater adverse effect on cognitive function in the elderly patients with lung cancer than sevoflurane. The pooled SMD or WMD in issues of preoperative MMSE scores suggested no statistical difference (SMD -0.038, 95\% CI: - 0.274, 0.198; WMD $0.040,95 \%$ CI: $-0.288,0.208 ; \mathrm{Z}=0.31 ; P=0.753)$. Then the pooled SMD in issues of postoperative MMSE scores at different time points were calculated using the random-effects model (except the MMSE score-7d). There were significant differences in issues of MMSE $6 \mathrm{~h}$ (11 studies; SMD -1.391, 95\% CI -2.024, - 0.757; WMD $-1.922,95 \%$ CI $-2.571,-1.274 ; p<0.001)$, MMSE $24 \mathrm{~h}$ (14 studies; SMD -1.106, 95\% CI -1.588, - 0.624; WMD $-1.504,95 \%$ CI $-2.253,-0.755 ; \mathrm{p}<0.001)$, MMSE 3d (11 studies; SMD $-1.065,95 \%$ CI -1.564, - 0.566; WMD -1.376, 95\% CI -2.044, - 0.708; p < 0.001), MMSE 7d (10 studies; SMD -0.422, 95\% CI -0.549, - 0.295; WMD $-0.371,95 \%$ CI $-0.493,-0.249 ; \mathrm{p}<0.001$ ), and the serum S100beta concentration at 1 day after surgery (13 studies; SMD 0.746, 95\% CI 0.475, 1.017; WMD 0.018, 95\% CI
0.016, 0.020; $p<0.001$ ) (Fig. 3). We assessed the risk of bias using the Cochrane risk of bias tool [11]. Table 6 reported detailed results from the risk of a bias assessment tool.

\section{Sensitivity analysis}

To assess if a single study could affect the final SMDs, each study was removed one time, and the data repooled. The analysis results demonstrated that the pooled SMDs were not affected by deleting every single study. Figure 4 showed sensitivity analysis results in issues of postoperative pain and propofol/remifentanil use.

\section{Publication bias}

The contour-enhanced funnel plots (this term's explanation could be seen in Table 3) were adopted to estimate potential publication biases, showing that most of the studies had missing areas for low statistical significance 
Table 4 Searching strategies and results for different databases (cut-off date: April 20, 2017)

\begin{tabular}{|c|c|c|c|c|}
\hline Database & Database URL & \multicolumn{2}{|l|}{ Search strategy } & Results \\
\hline Pubmed & $\begin{array}{l}\text { https://www.ncbi.nlm.nih. } \\
\text { gov/pubmed/ }\end{array}$ & \multicolumn{2}{|c|}{$\begin{array}{l}\text { ("sevoflurane" [Supplementary Concept] OR "sevoflurane" } \\
\text { [All Fields]) AND ("propofol" [MeSH Terms] OR "propofol" } \\
\text { [All Fields]) AND ("lung" [MeSH Terms] OR "lung" [All Fields]) }\end{array}$} & 108 \\
\hline Embase & https://www.embase.com/ & \multicolumn{2}{|c|}{$\begin{array}{l}\text { ('sevoflurane'/exp. OR sevoflurane) AND ('propofol'/exp. } \\
\text { OR propofol) AND ('lung'/exp. OR lung) }\end{array}$} & 1131 \\
\hline $\begin{array}{l}\text { Cochrane } \\
\text { Library }\end{array}$ & $\begin{array}{l}\text { http://www.cochranelibrary. } \\
\text { com/ }\end{array}$ & \multicolumn{2}{|l|}{ Sevoflurane AND Propofol AND lung:ti, ab, kw } & 148 \\
\hline $\begin{array}{l}\text { Web of } \\
\text { Science }\end{array}$ & $\begin{array}{l}\text { http://apps. } \\
\text { webofknowledge.com/ }\end{array}$ & \multicolumn{2}{|c|}{$\begin{array}{l}\text { TOPIC: (Sevoflurane AND Propofol AND postoperative } \\
\text { AND pain); Timespan: All years. } \\
\text { Indexes: SCI-EXPANDED, SSCI, A\&HCI, ESCl. }\end{array}$} & 195 \\
\hline CNKI & http://www.cnki.net/ & \multicolumn{2}{|c|}{$\begin{array}{l}\text { Search conditions: (topic = sevoflurane propofol lung cancer) } \\
\text { (fuzzy matching), album navigation: all; database: literature } \\
\text { cross-database search; search method: cross-database search } \\
\text { Database: Literature }\end{array}$} & 44 \\
\hline \multicolumn{5}{|c|}{ Searching results and information of relevant academic meeting abstracts } \\
\hline Year & City & Meeting name & Article title & $\begin{array}{l}\text { Whether } \\
\text { included }\end{array}$ \\
\hline 2015 & Beijing, P.R. China & $\begin{array}{l}\text { Chinese seminar on translational medicine and } \\
\text { integrative medicine }\end{array}$ & $\begin{array}{l}\text { Difference of postoperative cognitive } \\
\text { functions under propofol or sevoflurane } \\
\text { anesthesia for lung cancer surgery }\end{array}$ & No \\
\hline
\end{tabular}

(the left-hand side of the plot), indicating no publication bias in present studies (Fig. 5).

\section{Discussion}

The potential risk for cognitive impairment following surgery and anesthesia is a common concern, especially in the elderly and more fragile patients. The risk for various neurocognitive effects is thus an area of importance. The independent impact of surgery and anesthesia is still not known. Likewise, the independent effect of different drugs used during anesthesia is a matter of debate, as is the number and amounts of drugs used and the "depth of anesthesia." So, understanding the drugrelated phenomenon and mechanisms for postoperative cognitive impairment is essential. This meta-analysis aims to compare the effects of propofol and sevoflurane anesthesia on postoperative cognitive function in elderly patients with lung cancer. This meta-analysis compared the effects of propofol and sevoflurane anesthesia on postoperative cognitive function in elderly patients (> 60-year-old) with lung cancer. Results suggested that propofol has a more significant adverse effect on cognitive function in elderly patients with lung cancer than sevoflurane. There were significant differences in issues of MMSE $6 \mathrm{~h}$, MMSE 24 h, MMSE 3d, MMSE 7d, and the serum S100beta concentration at 1 day after surgery (all $p<0.01$ ). Regarding the two drugs analyzed, the halflife of elimination of propofol has been estimated to be between 2 and $24 \mathrm{~h}$. However, its duration of clinical effect is much shorter, because propofol is rapidly distributed into peripheral tissues. When used for IV sedation, a single dose of propofol typically wears off within minutes. The half-life of elimination of sevoflurane is $15-23 \mathrm{~h}$.

At present, there is no uniform standard for the assessment of cognitive dysfunction in the world, and the most commonly used standard clinically is the MMSE score [26]. Studies found that the sensitivity and specificity of the MMSE method for assessing cognitive brain function were 87 and $82 \%$, respectively [27]. The MMSE method is feasible and straightforward and is widely used for the screening of clinical cognitive dysfunction and cognitive decline [28]. The results of this metaanalysis showed that the MMSE scores at $6 \mathrm{~h}, 1 \mathrm{~d}, 3 \mathrm{~d}$, and $7 \mathrm{~d}$ after intravenous propofol anesthesia were significantly lower than those of sevoflurane. The reason may be that the sevoflurane has a shorter action time and is eliminated quickly. Laboratory data also showed that rats pretreated with high concentrations of sevoflurane could be effectively protected from focal cerebral ischemia, thus reducing neurological deficit scores, the volume of cerebral infarction, and cerebral edema areas. The incidence of post-cognitive disorders is adversely associated with higher concentrations of sevoflurane as a potential protective factor in non-cardiovascular procedures [29]. Experimental data have demonstrated that it may be because of the up-regulation of the expression levels of NR1 and NR2 subunits of hippocampal Nmethyl-D-aspartate receptors that sevoflurane has a slighter effect on cognitive function in the elderly patients than propofol [30].

On a contour-enhanced funnel plot, contours of statistical significance are overlaid on the funnel plot. Adding contours of statistical significance facilitates the assessment 


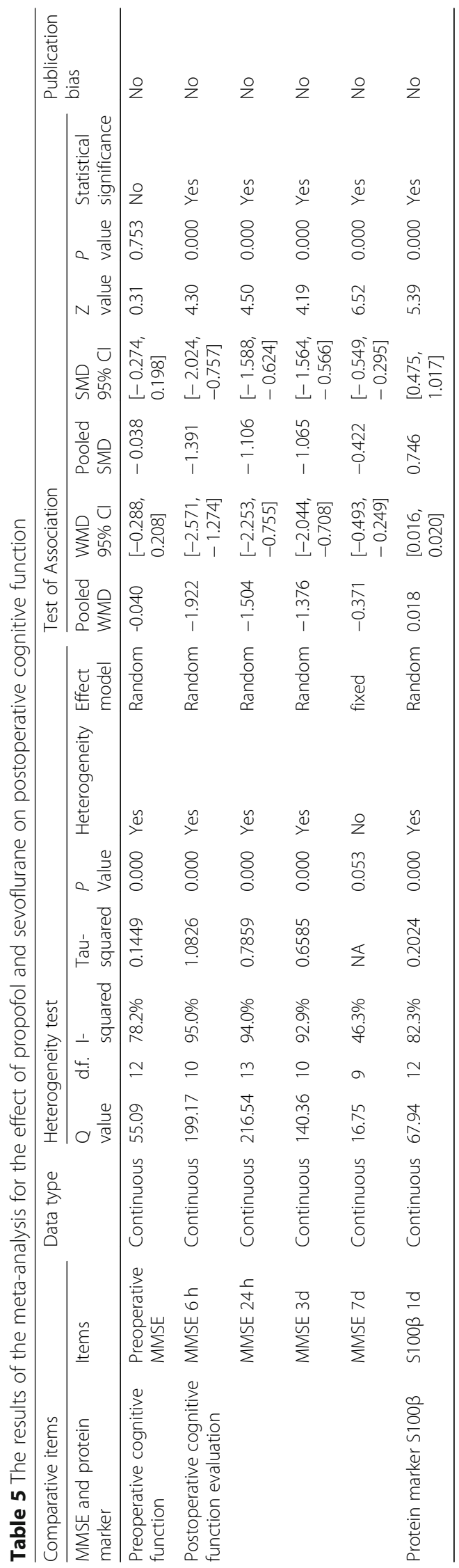




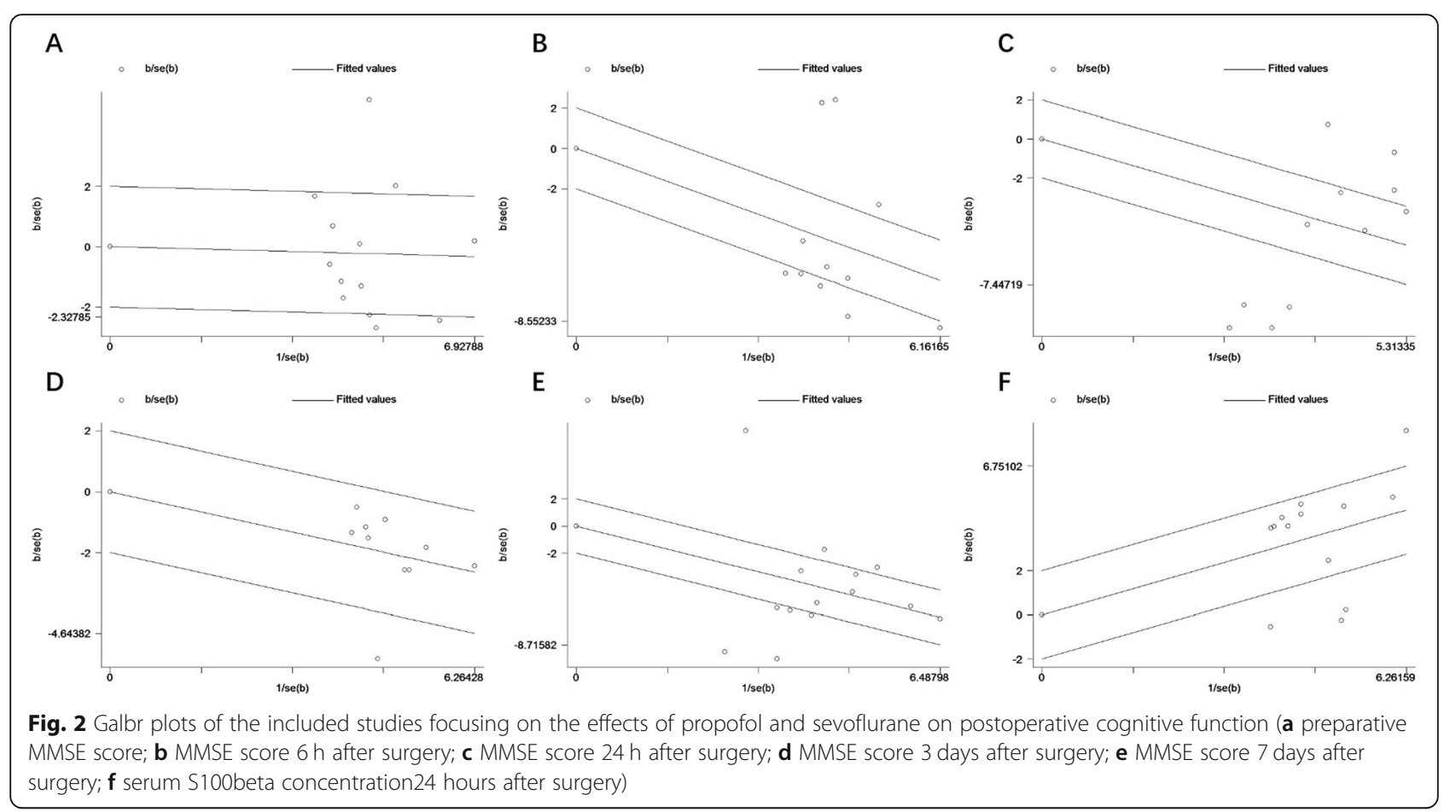

of whether the areas where studies exist are areas of statistical significance and whether the areas where studies are potentially missing correspond to areas of low statistical significance. Generally, if studies appear to be missing in areas of low statistical significance, then it is possible that the asymmetry is due to publication bias. Conversely, studies perceived to be missing areas of high statistical significance likely do not suffer from publication bias as a source of funnel asymmetry. In the present meta-analysis, the funnel plot indicated no publication bias.

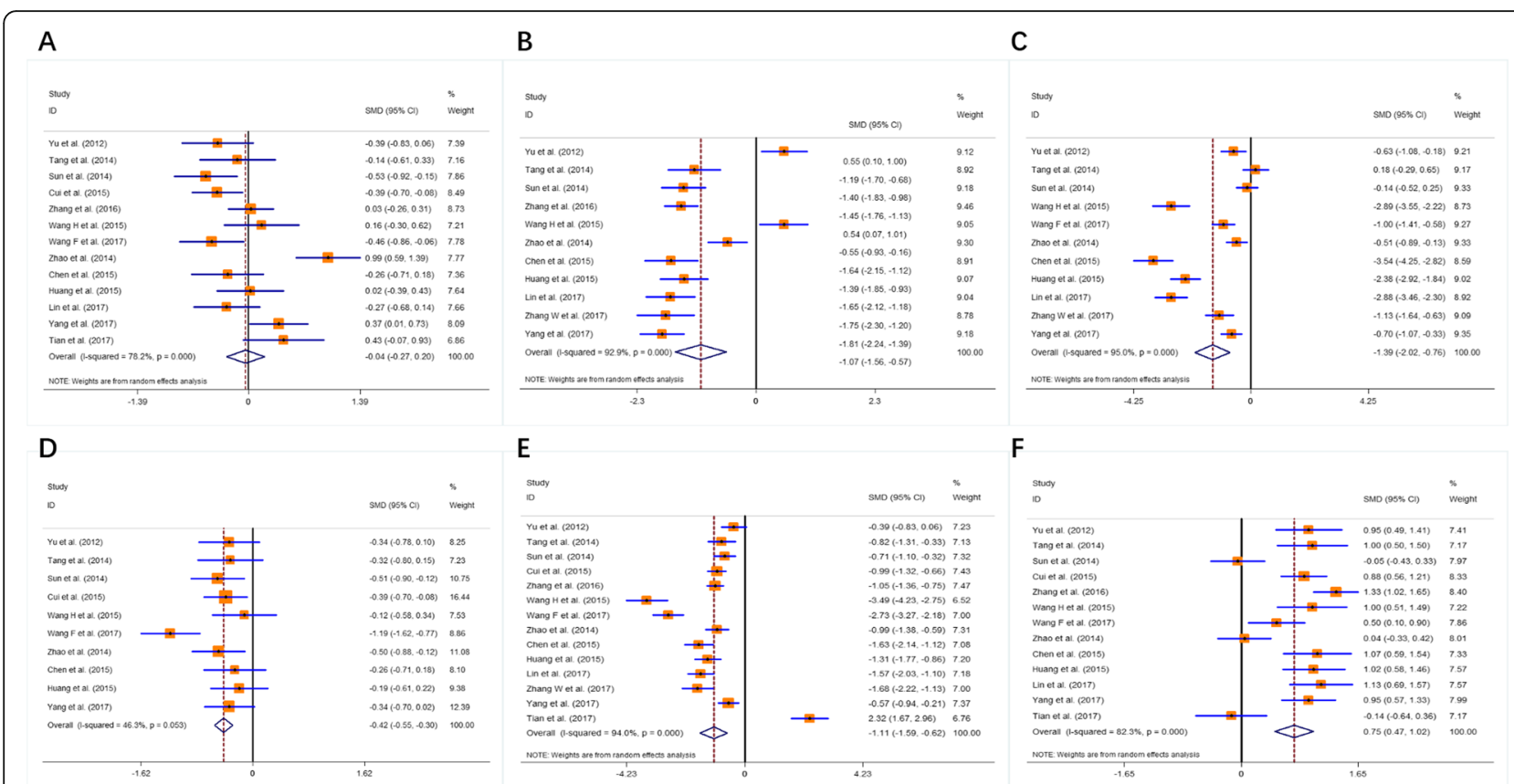

Fig. 3 Forest plots of the included studies focusing on the effects of propofol and sevoflurane on postoperative cognitive function (a preparative MMSE score; b MMSE score $6 \mathrm{~h}$ after surgery; c MMSE score $24 \mathrm{~h}$ after surgery; d MMSE score 3 days after surgery; e MMSE score 7 days after surgery; f serum S100beta concentration $24 \mathrm{~h}$ after surgery) 
Table 6 Study quality: review authors' judgments about each risk of bias item for each included study

\begin{tabular}{|c|c|c|c|c|c|c|c|c|}
\hline Author & Year & $\begin{array}{l}\text { Random sequence } \\
\text { generation }\end{array}$ & $\begin{array}{l}\text { Allocation } \\
\text { concealment }\end{array}$ & $\begin{array}{l}\text { Blinding of participants } \\
\text { and personnel }\end{array}$ & $\begin{array}{l}\text { Blinding of outcome } \\
\text { assessment }\end{array}$ & $\begin{array}{l}\text { Incomplete } \\
\text { outcome data }\end{array}$ & $\begin{array}{l}\text { Selective } \\
\text { reporting }\end{array}$ & $\begin{array}{l}\text { Other } \\
\text { sources of } \\
\text { bias }\end{array}$ \\
\hline Yu et al. & 2012 & Unclear risk & Unclear risk & Unclear risk & Unclear risk & Low risk & Unclear risk & Unclear risk \\
\hline $\begin{array}{l}\text { Tang } \\
\text { et al. }\end{array}$ & 2014 & Unclear risk & Unclear risk & Unclear risk & Unclear risk & Low risk & Unclear risk & Unclear risk \\
\hline $\begin{array}{l}\text { Sun } \\
\text { et al. }\end{array}$ & 2014 & Unclear risk & Unclear risk & Unclear risk & Unclear risk & Low risk & Unclear risk & Unclear risk \\
\hline $\begin{array}{l}\text { Cui } \\
\text { et al. }\end{array}$ & 2015 & Unclear risk & Unclear risk & Unclear risk & Unclear risk & Low risk & Unclear risk & Unclear risk \\
\hline $\begin{array}{l}\text { Zhang } \\
\text { et al. }\end{array}$ & 2016 & Unclear risk & Unclear risk & Unclear risk & Unclear risk & Low risk & Unclear risk & Unclear risk \\
\hline $\begin{array}{l}\text { Wang } \mathrm{H} \\
\text { et al. }\end{array}$ & 2015 & Unclear risk & Unclear risk & Unclear risk & Unclear risk & Low risk & Unclear risk & Unclear risk \\
\hline $\begin{array}{l}\text { Wang F } \\
\text { et al. }\end{array}$ & 2017 & $\begin{array}{l}\text { Random number } \\
\text { table }\end{array}$ & Unclear risk & Unclear risk & Unclear risk & Low risk & Unclear risk & Unclear risk \\
\hline $\begin{array}{l}\text { Zhao } \\
\text { et al. }\end{array}$ & 2014 & Unclear risk & Unclear risk & Unclear risk & Unclear risk & Low risk & Unclear risk & Unclear risk \\
\hline $\begin{array}{l}\text { Chen } \\
\text { et al. }\end{array}$ & 2015 & Unclear risk & Unclear risk & Unclear risk & Unclear risk & Low risk & Low risk & Unclear risk \\
\hline $\begin{array}{l}\text { Huang } \\
\text { et al. }\end{array}$ & 2015 & $\begin{array}{l}\text { Random number } \\
\text { table }\end{array}$ & Unclear risk & Unclear risk & Unclear risk & Low risk & Unclear risk & Unclear risk \\
\hline Lin et al. & 2017 & Unclear risk & Unclear risk & Unclear risk & Unclear risk & Low risk & Unclear risk & Unclear risk \\
\hline $\begin{array}{l}\text { Zhang } \\
\text { et al. }\end{array}$ & 2017 & Unclear risk & Unclear risk & Unclear risk & Unclear risk & Low risk & Unclear risk & Unclear risk \\
\hline $\begin{array}{l}\text { Yang } \\
\text { et al. }\end{array}$ & 2017 & Low risk & Unclear risk & Unclear risk & Unclear risk & Low risk & Low risk & Unclear risk \\
\hline $\begin{array}{l}\text { Tian } \\
\text { et al. }\end{array}$ & 2017 & Low risk & Unclear risk & Unclear risk & Unclear risk & Low risk & Low risk & Unclear risk \\
\hline
\end{tabular}

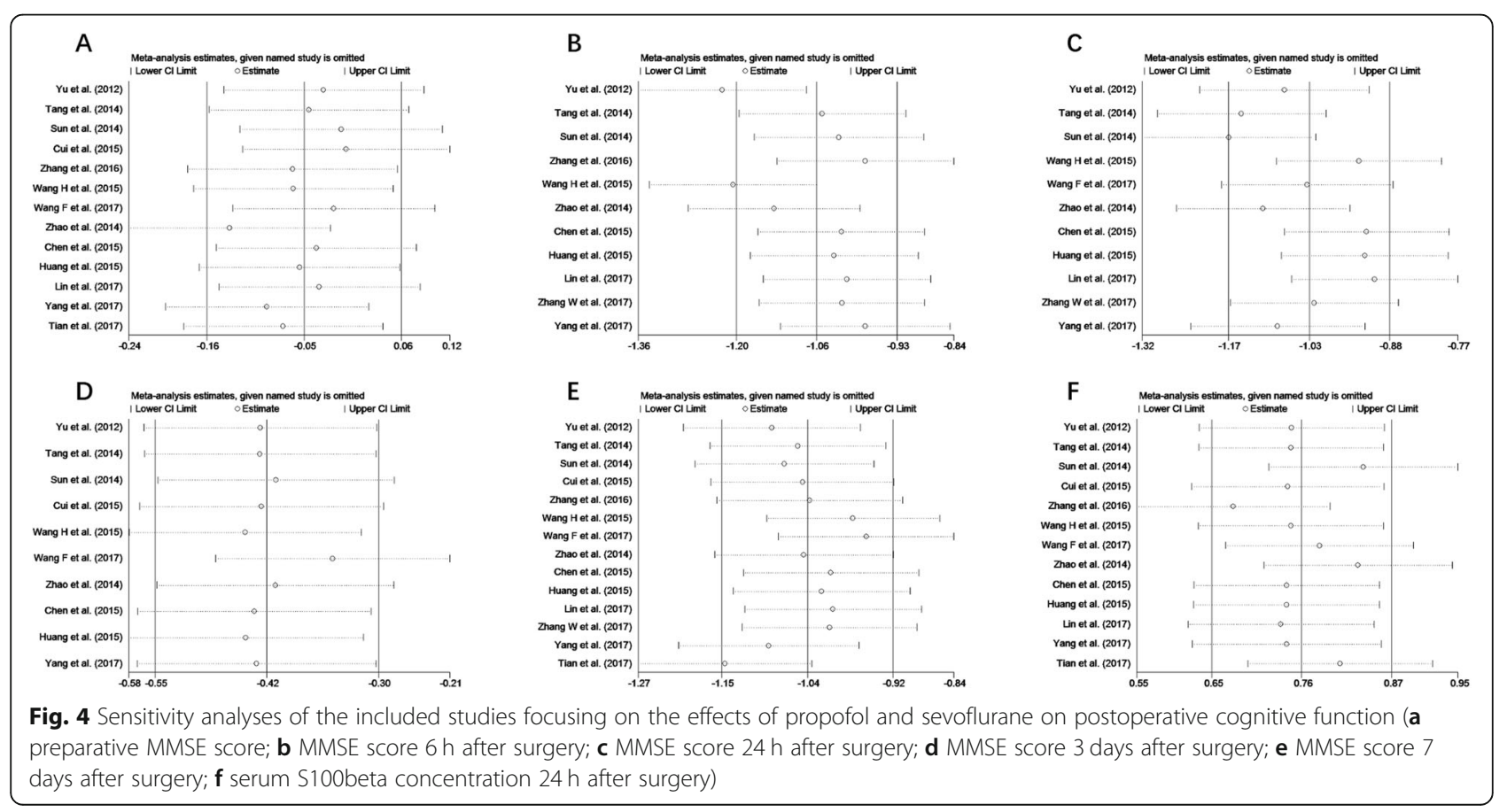




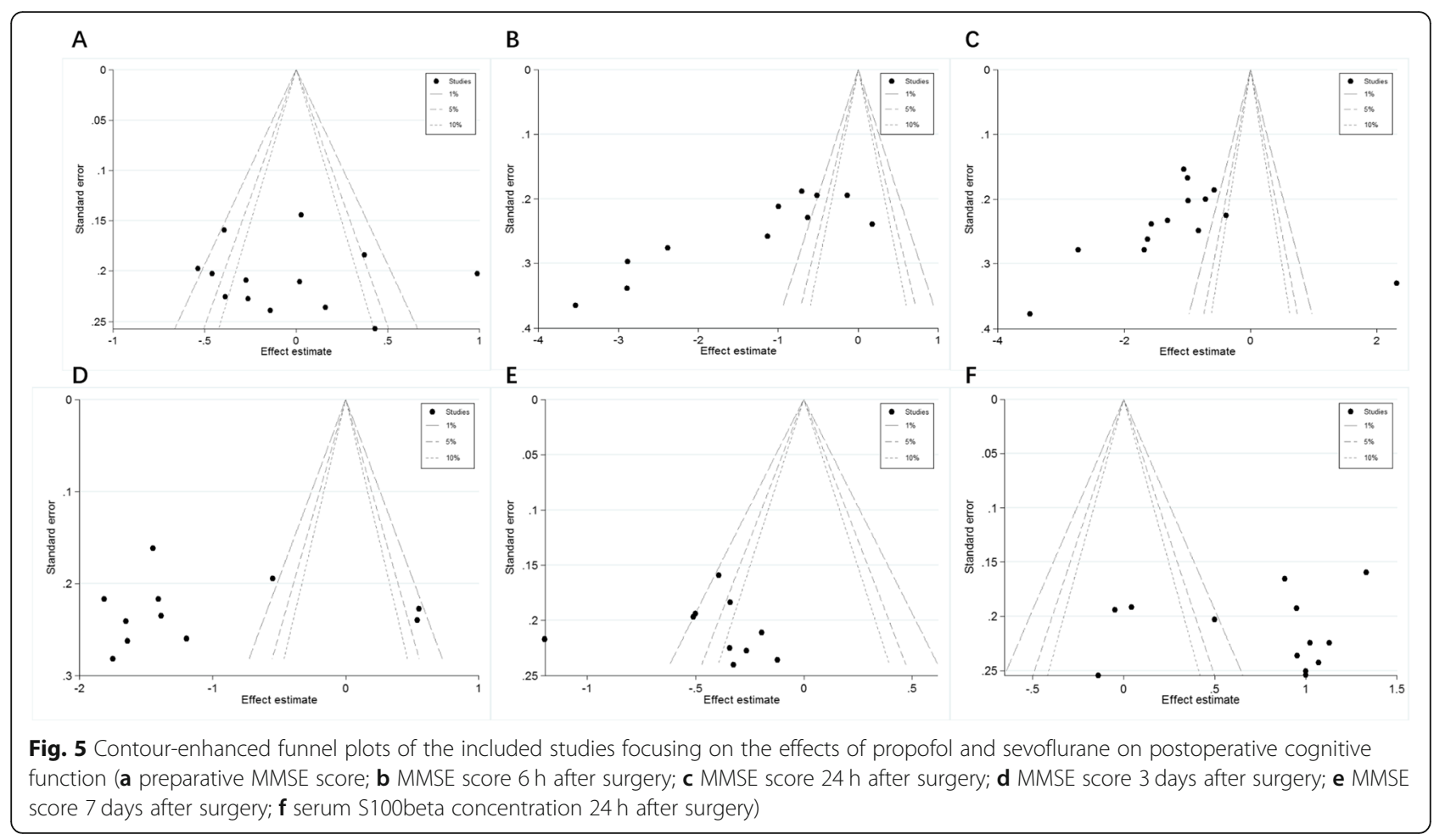

This meta-analysis has a few limitations. Firstly, we included only 14 articles. Although all these studies were conducted with propofol anesthesia and sevoflurane anesthesia as the experimental group and the control group, respectively, the doses of the drugs used for the elderly patients with lung cancer, the length of the operation time, and the use of adjuvant drugs were not the same. So, the problem of generalizability might exist. Secondly, most literature tends to report positive outcomes, while the studies with negative results are often not reported. Though not suggested via contourenhanced funnel plots, the possibility of potential publication bias in included studies should not be overlooked. Thirdly, we did not perform a grey literature search, which might cause overestimations of effect sizes. Grey literature stands for manifold document types produced on all levels of government, academics, business and industry in print and electronic formats that are protected by intellectual property rights, of sufficient quality to be collected and preserved by libraries and institutional repositories, but not controlled by commercial publishers; i.e. where publishing is not the primary activity of the producing body. Fourthly, there are several tools more extensive tools available for assessment of recovery; however, in the present study, we only adopted MMSE as the outcome because of the data availability (MMSE is the most commonly used for screening). Although one may argue that merely presenting repeated MMSE scores is not sufficient for assessment of cognitive capacity and discriminating differences between groups, we believe that at this present time, due to the data availability mentioned above, the MMSE could say something. Fifthly, most of the included studies did not report enough the details of each patient, so it is not easy to separate between emergence reaction within hours from emergence, early cognitive changes - delirium and more protracted changes. Additionally, the many included studies had a relatively low methodology quality, so more rigorous large-scale randomized controlled trials are needed. Sixthly, the vast majority of the studies were conducted in China. The inter-racial variability of propofol anesthesia is well described. Therefore, it is not sure if the results are valid for other races. Seventhly, as is understood, co-administered drugs differed in included studies, but did any of the studies include regional anesthetic techniques? Could the greater peri-operative hypotension sometimes see with propofol have been a cause? Due to lacking these related data, the accuracy of the study's conclusions will be questioned.

\section{Conclusions}

In summary, propofol has a more significant adverse effect on postoperative cognitive function in lung cancer patients than sevoflurane. In the included studies, some of the documents are of low quality and may affect the stability and reliability of the final results. Therefore, larger samples, more rigorous design, and higher quality tests are still needed for verification. 


\section{Abbreviations}

ASA: America Society of Anesthesiologist; Cl: Confidence interval; CNKI: China National Knowledge Infrastructure; CNS: Central nervous system; MMSE: Minimental state examination; SMD: Standard mean difference

\section{Acknowledgements}

We thank our colleagues at the Department of Anesthesiology, National Cancer Center/National Clinical Research Center for Cancer/Cancer Hospital, Chinese Academy of Medical Sciences and Peking Union Medical College, Beijing, 100021, China.

\section{Authors' contributions}

$\mathrm{HS}, \mathrm{BA}$, and XK contributed to the data collection and paper drafting; $\mathrm{GZ}, \mathrm{HZ}$, $\mathrm{XK}$ and WL contributed to the data analyzing; TY, HZ and LS contributed to the literature reviewing. All authors read and approved the final manuscript.

\section{Funding}

1. Beijing Hope Marathon Special Fund of Chinese Cancer Foundation (LC2017B25)

2. Natural Science Foundation of Inner Mongolia Autonomous Region of China (2015MS0835)

3. Teaching Reform Project of Peking Union Medical College (10023201800307)

4. Sanming Project of Medicine in Shenzhen, Cancer Pain Treatment and Perioperative Medical Team of Professor Li Sun in Cancer Hospital, Chinese Academy of Medical Sciences.

5. Special Research Fund for Central Universities, Peking Union Medical College (3332019050)

6. Special Research Fund for Central Universities, Peking Union Medical College (3332019053)

7. Special Research Fund for Central Universities, Peking Union Medical College (3332019140)

8. Beijing Municipal Natural Science Foundation (7204293)

The funders had no role in study design, data collection and analysis, decision to publish, or preparation of the manuscript.

\section{Availability of data and materials}

All data has been included in the manuscript.

\section{Ethics approval and consent to participate}

Because this is only a systematic review of previous retrospective studies and does not involve any human experiments or animal experiments, ethics approval and consent are not applicable.

\section{Consent for publication}

Not applicable.

\section{Competing interests}

The authors declare that they have no competing interests.

\begin{abstract}
Author details
${ }^{1}$ Department of Anesthesiology, National Cancer Center/National Clinical Research Center for Cancer/Cancer Hospital, Chinese Academy of Medical Sciences and Peking Union Medical College, Beijing 100021, China. ${ }^{2}$ Department of Breast Surgical Oncology, National Cancer Center/National Clinical Research Center for Cancer/Cancer Hospital, Chinese Academy of Medical Sciences and Peking Union Medical College, Beijing 100021, China. ${ }^{3}$ Department of Gastroenterology, Inner Mongolia's Peoples' Hospital, Inner Mongolia 010000, China. ${ }^{4}$ Mater Hospital Brisbane Queensland Medical Program, The University of Queensland, Brisbane, Australia. ${ }^{5}$ Department of Anesthesiology, National Cancer Center/National Clinical Research Center for Cancer/Cancer Hospital \& Shenzhen Hospital, Chinese Academy of Medical Sciences and Peking Union Medical College, Shenzhen 518116, China.
\end{abstract}

Received: 28 May 2019 Accepted: 3 December 2019

Published online: 23 December 2019

\section{References}

1. Sheelakumari R, Kesavadas C, Lekha VS, Justus S, Sarma PS, Menon R. Structural correlates of mild cognitive impairment: a clinicovolumetric study. Neurol India. 2018;66(2):370-6.
2. Gupta A, Murthy P, Rao S. Brief screening for cognitive impairment in addictive disorders. Indian J Psychiatry. 2018;60(Suppl 4):S451-6.

3. Weiser TG, Regenbogen SE, Thompson KD, Haynes AB, Lipsitz SR, Berry WR, Gawande AA. An estimation of the global volume of surgery: a modelling strategy based on available data. Lancet. 2008;372(9633):139-44.

4. Monk TG, Weldon BC, Garvan CW, Dede DE, van der Aa MT, Heilman KM, Gravenstein JS. Predictors of cognitive dysfunction after major noncardiac surgery. Anesthesiology. 2008;108(1):18-30.

5. Price CC, Garvan CW, Monk TG. Type and severity of cognitive decline in older adults after noncardiac surgery. Anesthesiology. 2008;108(1):8-17.

6. Peng $L, X u L$, Ouyang $W$. Role of peripheral inflammatory markers in postoperative cognitive dysfunction (POCD): a meta-analysis. PLoS One. 2013;8(11):e79624.

7. Moller JT, Cluitmans P, Rasmussen LS, Houx P, Rasmussen H, Canet J, Rabbitt P, Jolles J, Larsen $\mathrm{K}$, Hanning CD, et al. Long-term postoperative cognitive dysfunction in the elderly ISPOCD1 study. ISPOCD investigators. International study of post-operative cognitive dysfunction. Lancet. 1998;351(9106):857-61.

8. Didkowska J, Wojciechowska U, Manczuk M, Lobaszewski J. Lung cancer epidemiology: contemporary and future challenges worldwide. Ann Transl Med. 2016;4(8):150.

9. Siegel RL, Miller KD, Jemal A. Cancer statistics, 2017. CA Cancer J Clin. 2017;67(1):7-30.

10. Lim JA, Oh CS, Yoon TG, Lee JY, Lee SH, Yoo YB, Yang JH, Kim SH. The effect of propofol and sevoflurane on cancer cell, natural killer cell, and cytotoxic T lymphocyte function in patients undergoing breast cancer surgery: an in vitro analysis. BMC Cancer. 2018;18(1):159.

11. Bertizzolo L, Bossuyt P, Atal I, Ravaud P, Dechartres A. Disagreements in risk of bias assessment for randomised controlled trials included in more than one Cochrane systematic reviews: a research on research study using crosssectional design. BMJ Open. 2019;9(4):e028382.

12. Tang CJ, Xu SY. A comparative study for the influences on elderly patients with lung cancer anaesthetized with sevoflurane and propofol. Chin J Gerontol. 2014;34(13):3566-8.

13. Yang HW, Tian ZR, Zhang HB. Comparative study on influence of anesthesia with sevoflurane or Propofol on postoperative cognitive function in elder patients with lung Cancer. World Latest Med Inform. 2017;17(1):12-3.

14. Zhang W, Yang F. Comparison of the effects of seven sevoflurane and Propofol anesthesia on postoperative cognitive function in elderly patients with lung Cancer. China Contin Med Educ. 2017;9(26):69-70.

15. Wang F, Sun HL. Effect of sevoflurane or Propofol anesthesia on the postoperative cognitive function of senile patients with lung Cancer. China Foreign Med Treat. 2017;36(12):131-3.

16. Tian HT, Duan XH, Yang YF, Wang Y, Bai QL, Zhang X. Effects of propofol or sevoflurane anesthesia on the perioperative inflammatory response, pulmonary function and cognitive function in patients receiving lung cancer resection. Eur Rev Med Pharmacol Sci. 2017;21(23):5515-22.

17. Cui W. Effects of sevoflurane and propofol on the elderly patients with lung cancer. Healthy Living. 2015;14(8):28.

18. Lin KX, Fang XK. Effects of sevoflurane and propofol on the elderly patients with lung cancer. Guide China Med. 2017;15(17):69-70.

19. Sun YC, Wang DT, Yu JH. Influence of anesthesia with sevoflurane or propofol on postoperative cognitive function in elder patients of lung cancer. China Prac Med. 2014;9(7):5-6.

20. Yu XC, Wang YG, Gao LB, Zhao HW. Influence of anesthesia with sevoflurane or propofol on postoperative cognitive function in elder patients of lung cancer. J Tianjin Med Univ. 2012;18(1):102-5.

21. Zhao LM, Wu LX, Yang BH, Xia YS. Influence of anesthesia with sevoflurane or propofol on postoperative cognitive function in elder patients of lung cancer. J Qiqihar Univ Med. 2014;35(21):3190-1.

22. Chen ZQ. Influence on elderly patients with lung cancer anaesthetized with sevoflurane and propofol. Chin J Mod Drug Appl. 2015;9(15):167-8.

23. Zhang $\mathrm{YH}$, Chen $\mathrm{HM}$, Zhang $\mathrm{Q}$, Han MQ. The influences of sevoflurane or propofol on postoperative cognitive function in elder patients of lung cancer. Chin J of Clinical Rational Drug Use. 2016;9(5A):97-8.

24. Hung DH, Han Q, Liu CY. Influences of sevoflurane and propofol on the elderly patients with lung cancer. Chin J Gerontol. 2015;35(14):3961-3.

25. Wang $H T$, Jiang HM. To compare the influences on elderly patients with lung cancer anaesthetized with sevoflurane and propofol. Inner Mongolia Med J. 2015;47(8):979-81.

26. Hemerka JN, Wu X, Dixon CE, Garman RH, Exo JL, Shellington DK, Blasiole B, Vagni VA, Janesko-Feldman $\mathrm{K}$, Xu M, et al. Severe brief pressure-controlled hemorrhagic shock after traumatic brain injury exacerbates functional 
deficits and long-term neuropathological damage in mice. J Neurotrauma. 2012;29(12):2192-208.

27. Niwa H, Koumoto C, Shiga T, Takeuchi J, Mishima S, Segawa T, Atsumi T, Shimizu C, Koike T, Yoshioka N. Clinical analysis of cognitive function in diabetic patients by MMSE and SPECT. Diabetes Res Clin Pract. 2006;72(2):142-7.

28. Kong HY, Cheng DM, Pang W, Sun SD, Liu J, Huang CY, Jiang YG.

Homocysteine levels and cognitive function scores measured with MMSE and BCAT of middle-aged and elderly subjects in Tianjin City. J Nutr Health Aging. 2013;17(6):527-32

29. Xu T, Bo L, Wang J, Zhao Z, Xu Z, Deng X, Zhu W. Risk factors for early postoperative cognitive dysfunction after non-coronary bypass surgery in Chinese population. J Cardiothorac Surg. 2013;8:204.

30. Haseneder R, Starker L, Berkmann J, Kellermann K, Jungwirth B, Blobner M, Eder M, Kochs E, Rammes G. Sevoflurane anesthesia improves cognitive performance in mice, but does not influence in vitro long-term potentation in hippocampus CA1 stratum radiatum. PLoS One. 2013;8(5):e64732.

\section{Publisher's Note}

Springer Nature remains neutral with regard to jurisdictional claims in published maps and institutional affiliations.

Ready to submit your research? Choose BMC and benefit from:

- fast, convenient online submission

- thorough peer review by experienced researchers in your field

- rapid publication on acceptance

- support for research data, including large and complex data types

- gold Open Access which fosters wider collaboration and increased citations

- maximum visibility for your research: over $100 \mathrm{M}$ website views per year

At BMC, research is always in progress.

Learn more biomedcentral.com/submissions 